\title{
Is Gold a Hedge Against Turkish Lira?
}

Feride Ozturk, Sezgin Acikalin*

\section{Abstract}

This paper investigates whether gold is an internal hedge and/or an external hedge against Turkish lira (TL) by using monthly data from January 1995 to November 2006. Cointegration test results confirm the long-term relationships between the gold price and consumer price index and between the gold price and TL/US dollar exchange rate. The Granger Tests, based on vector error correction model (VECM), indicate that gold price Granger causes the consumer price index and TL/US dollar exchange rate in a unidirectional way. It is concluded that gold acts as an effective hedge against potential future TL depreciation and rising domestic inflation. Furthermore, gold price may be considered as a good indicator of inflation and hence it can be used as a guide to monetary policy.

JEL : E31, F31, G10

\section{Introduction}

Apart from its use in industrial and medical applications and jewelry, gold has played an important role in the world's economy for thousands of years. The World Council (2005:3-4) states: "Gold is an effective hedge against inflation. In addition, gold is inversely correlated to the US dollar, making it a good currency hedge"; "Gold is a highly effective portfolio diversifier due to its low to negative correlation with all major asset classes"; and "In much of Asia, the Middle East, and the Indian subcontinent, gold is the best possible protection against upheaval both political and economic". The rise in gold prices from $\$ 250$ per ounce in 2001 to over $\$ 650$ in 2007 has made interest soar in gold as a financial asset and an economic indicator. It is as popular today as ever.

Buying and holding gold per se should not be considered an investment, at least in the classical sense. If so, why would one prefer investing in gold? Holding gold might be seen somewhat the same as keeping one's savings under the mattress as paper currency. Well, not quite the same, since one looses purchasing power by holding paper currency. However, the price of gold increases, or the purchasing power of gold goes up, if the paper currency depreciates. Accordingly, one might prefer holding gold to
DOI: 10.2478/v10033-008-0004-x protect against a loss in the purchasing power of the paper currency.

Capie et al. (2005) argued that gold could be a hedge in two ways. The first is a hedge against changes in the internal purchasing power of the domestic currency, while the second one is a hedge against changes in the external purchasing power of the domestic currency. In other words, gold offers protection against a weak currency or high domestic inflation levels. If gold is considered to

\footnotetext{
* Ozturk:

Dunlupinar University,

Department of Economics,

Tavsanli Yolu 10.Km, Kutahya, Turkey

e-mail: fozturk@dumlupinar.edu.tr

* Acikalin:

Dunlupinar University,

Department of Economics,

Tavsanli Yolu 10.Km, Kutahya, Turkey

e-mail: sezgina@anadolu.edu.tr
} 
be a perfect internal hedge, its domestic currency price should increase at the same rate as domestic price index. If it is a perfect external hedge, its domestic currency price should increase at the same rate as the domestic currency depreciation.

In this paper, motivated by the renewed interest in gold, it is aimed to determine whether gold is an internal hedge and/or an external hedge against TL. Data used in the analyses runs from January 1995 through November 2006. It is used time series unit root tests to examine the stationary properties of the price of gold (GP), consumer price index $(\mathrm{CPI})$, and TL/US dollar exchange rate series. The cointegration framework of Johansen (1988) was applied to test for cointegrating relationships. All tests provided evidence in favor of cointegration, and confirmed the existence of long-term relationships between GP and CPI and between GP and TL/US dollar exchange rate. Furthermore, in order to determine the causal relationships between CPI and GP and between TL/US dollar exchange rate and GP, Granger Causality test based on VECM was employed. The results indicated that GP Granger caused the $\mathrm{CPI}$ and TL/US dollar exchange rate (i.e., changes in GP preceded changes in the CPI and TL/US dollar exchange rate) in an unidirectional way. It is concluded that gold acts as an effective hedge against future possible TL depreciation and rising domestic inflation.

Findings also suggested that the gold price may be a good indicator of inflation and hence it can be used as a guide to monetary policy. However, it should be kept in mind that some factors, among others, economic and political factors in other countries, changes in foreign demand for gold, and world supplies of gold have an important role in determining gold prices.

The paper is organized as follows. Section II presents previous studies. Section III provides data, while section IV discusses methodology and presents results. Finally, section $\mathrm{V}$ concludes the paper.

\section{Previous Studies}

Gold has received an immense attention in the empirical literature. Sherman (1986), Jaffe (1989), Chua et al. (1990), Ciner (2001), and Michaud et al. (2006) have focused on the diversification benefits of portfolios including gold; Tandon and Urich (1988), Kitchen (1996), Christie-David et al. (2000), and Lucey and Tully (2006), among others, have examined the effect of macroeconomic news releases on gold prices. A number of studies have reported on the role gold plays as an effective hedge against inflation and possible currency depreciation and the role inflation and the possible domestic currency depreciation play on the gold price. Laurent (1994), for instance, investigated the relationship between the price of gold and wholesale price index in the United States. According to this study two variables closely corresponded over the period 1800-1992, while the price of gold was more volatile than the wholesale price index in the short term. Similarly, Harmston (1998) compared price of gold index, wholesale price index, and purchasing power of gold index (constructed by dividing the first index by the second) in the US (1796-1997), Britain (1596-1997), France (1820-1997), Germany (1873-1997), and Japan (1880-1997). In all five countries gold has been a tendency to return to an historic rate of exchange with other commodities and intermediate goods, meaning that gold is effective as a long-term hedge against inflation. Using monthly data from 1976 to 1999 and cointegration technique, Gosh et al. (2002) also found a long term relationship between the price of gold and US wholesale price index.

Recently, Levin and Wright (2006) investigated both sort term and long term determinants of gold price applying cointegration and VECM techniques over the period January 1976- August 2005. Their findings are three folds. First, there is a long term relationship between the price of gold and US price level. Second, there is a positive relationship between changes in the gold price and changes in US inflation, US inflation volatility, and credit risk, while there is a negative relationship between gold price movements and changes in the US dollar tradeweighted exchange rate and the gold lease rate. The last, in the major gold consuming countries such as Turkey, India, Indonesia, Saudi Arabia, and China gold is effective as a long term hedge against inflation. These studies present firm evidence about gold hedging. More specifically, gold retains inflation hedging properties in the long term despite considerable fluctuations in the short term.

Garner (1995) argued that the price of gold might be good leading indicator of inflation. When expected inflation rises, some investors might switch from financial assets with fixed nominal rates into gold or jewelry. Since the gold supply is relatively fixed, the price of gold might rise rapidly even with a small increase in gold demand. The inflation rate, however, tends to increase more slowly. Consequently, an increase in the price of gold might precede an increase in inflation rate. Reasoning from this point, turning point signals of the price of gold from 1960 to 1995 in the United States is evaluated in this study. It is found that the gold prices tended to signal past inflation upturns.

Mahdavi and Zhou (1997) compared the performance of gold and commodity prices as leading indicators of inflation applying cointegration tests and VECM over the periods 1958:QI-1994:Q4 and 1970:QI-1994:Q4. Their results indicated that out-of-sample forecast of gold is relatively poor which is consistent with the idea that in the short-term price of gold is too volatile. They concluded that the strength of the gold price signaling inflation may vary depending on the time span being examined. Ranson and Wainright (2005) demonstrated the extent to which 
the prices of gold and oil serve as leading indicators of unanticipated inflation and interest rates applying an ordinary least squares. They reported that the price of gold is the superior predictor of the next year inflation.

Capie et al. (2005) investigated the extent to which gold price acted as an exchange rate hedge by using weekly data over the period January, 8, 1971- February, 20, 2004. Their cross-correlations and EGARCH results indicated that there was a negative relationship between gold price and sterling-dollar and yen-dollar exchange rates but the strength of this relationship varied over time.

\section{Data}

The data consists of monthly observations of the GP, quoted in TL per gram, the CPI, and TL/US dollar exchange rate. The sample period running from January 1995 to November 2006 covers a total of 143 observations. The data for the gold price and TL/US dollar exchange rate were taken from the internet data resources of Central Bank of the Republic of Turkey, while the CPI data was from the Turkish Statistical Institute's resources.

Figures 1, 2, and 3 show GP, TL/US dollar exchange rate, and CPI series in levels over time, respectively. The price of gold has varied between the lowest, $0.49 \mathrm{TL}$ at the beginning of 1995 and the highest, 31.86 TL in July 2006. The gold price increased rapidly in the periods from the beginning of 2001 to the end of 2003 and from August 2005 to July 2006. TL followed a depreciation trend over the period of 1995-2002, while the depreciation turned out to be dramatic in 2001 and 2002. An apparent appreciation process of TL has seen from October 2004 to April 2006. Although it depreciated dramatically during May-July 2006 , has since held relatively stable. The CPI has been on an increasing trend during the sample period.

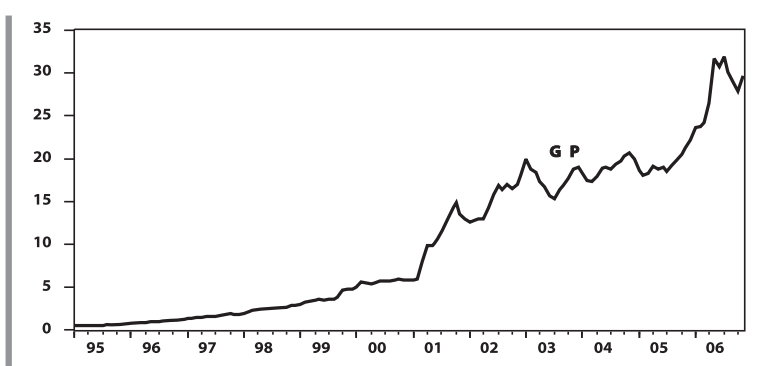

Figure 1. GP in TL, 1995-2006, (monthly)

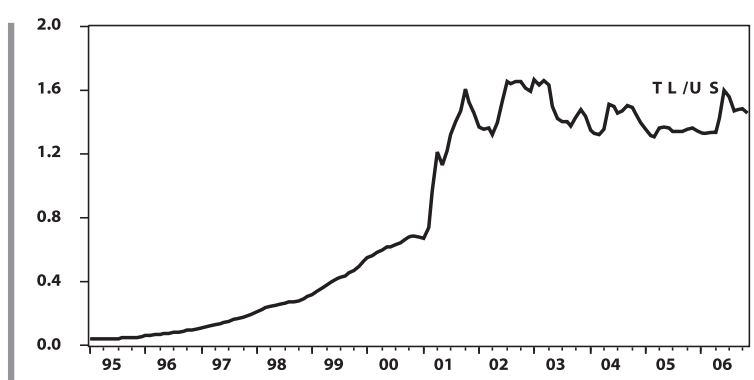

Figure 2. TL/ US dollar exchange rate, 1995-2006, (monthly)

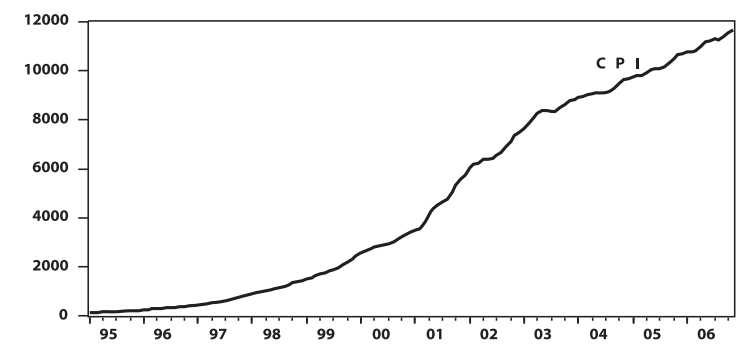

Figure 3. CPI, 1995-2006, (monthly)

\section{Empirical Methodology and Results}

Before investigating the cointegration relationships between GP and CPI and between GP and TL/US dollar exchange rate, Tramo-Seats method was used to deseasonalise all three series. Augmented Dickey-Fuller (1979) and Phillips-Perron (1988) tests were employed to examine stationarity of all interested variables. The rejection of null hypothesis indicating to unit roots in these tests is interpreted as consistent evidence of stationarity. Table 1 presents the unit root tests statistics for each series. Augmented Dickey-Fuller (ADF) and Phillips-Perron (PP) tests were applied with and without a time trend variable. It is evident that the null of a nonstationarity could not be rejected at the $5 \%$ level of significance for the GP, TL/US dollar exchange rate, and the CPI series with or without a time trend. Therefore, the tests were performed on first differences of series. The ADF and the PP test results, presented at the last three columns of the Table 1, indicate that all series are stationary in their first differences (I(1)). 


\section{Sample Period 01/1995 - 11/2006}

\begin{tabular}{|c|c|c|c|c|c|c|}
\hline \multirow[b]{3}{*}{ Test Statistic $c^{\mathrm{a}, \mathrm{b}}$} & \multicolumn{5}{|c|}{ Sample Period 01/1995 - 11/2006 } & \multirow[b]{3}{*}{ TL/US\$ } \\
\hline & \multicolumn{2}{|c|}{ Variables (levels) } & \multicolumn{2}{|c|}{ Variables (first differences) } & \multirow[b]{2}{*}{ CPI } & \\
\hline & GP & CPI & TL/US\$ & GP & & \\
\hline ADF (c) & $0.21(1)$ & $1.05(1)$ & $-0.90(1)$ & $-8.69(0)^{*}$ & $-4.17(0)^{*}$ & $-8.32(0)^{*}$ \\
\hline$A D F(t)$ & $-2.60(1)$ & $-2.5(1)$ & $-1.49(1)$ & $-8.75(0)^{*}$ & $-4.49(0)^{*}$ & $-8.30(0) *$ \\
\hline $\mathrm{PP}(\mathrm{c})$ & 0.50 & 1.75 & -0.82 & $-8.56^{*}$ & $-3.99 *$ & $-8.32 *$ \\
\hline PP (t) & -2.19 & -2.62 & -1.30 & $-8.59 *$ & $-4.33^{*}$ & $-8.30 *$ \\
\hline
\end{tabular}

\section{Table 1: Unit Root Tests}

aThe optimal lag length, which are the numbers in parenthesis along with the ADF test statistics, were chosen by using the Schwarz Information Criterion (SIC). ${ }^{b}(c)$ is for the model with a constant term but no time trend. $(t)$ is for the model with a constant term and a time trend.

* Denotes significance at the $1 \%$ level. The $1 \%$ critical values for the ADF test are -.3 .54 and -4.11 for the model with a constant and for the model with a constant term and a time trend, respectively. The $1 \%$ critical values for the PP test are -3.47 and -4.02 for the model with a constant and for the model with a constant term and a time trend, respectively. The $5 \%$ critical values for the ADF test are -.2 .91 and -3.48 for the model with a constant and for the model with a constant term and a time trend, respectively. The $5 \%$ critical values for the PP test are -.2 .88 and -3.44 for the model with a constant and for the model with a constant term and a time trend, respectively. The null hypothesis of the ADF and the PP tests is Ho: series contain a unit root versus $\mathrm{H} 1$ : series is stationary.

Engle and Granger (1987) argued that if two nonstationary series are cointegrated, meaning that the series contain common trend components, there may exist a long-term stable relationship between the two. Having determined the order of integration, cointegration framework of Johansen (1988) is used to ascertain whether CPI and GP and TL/US dollar exchange rate and GP are cointegrated. The results of the cointegration tests are reported in Table 2. Both the Maximum Eigenvalue and Trace Tests statistics indicate that the null hypothesis of no cointegrating vector, $r=0$, is rejected at the $5 \%$ significance level, and hence, there exists at least one cointegrating vector between CPI and GP and between TL/US dollar exchange rate and GP. As further test results show that the null of $r=1$ can not be rejected at the $5 \%$ level, implying that there is only one cointegrating vector between the pairs of variables. Therefore, it is concluded that there are long-term relationships between CPI and GP and between TL/US dollar exchange rate and GP.

Granger (1969) pointed out that if two variables are cointegrated, then Granger causality must exist in at least one direction, either unidirectional or bi-directional. He described a variable $x_{t}$ as Granger causing another variable $\mathrm{y}_{\mathrm{t}^{\prime}}$ if the inclusion of lagged values of $\mathrm{x}$ improves the forecast of $y$, or equivalently if the coefficients on the lagged $x$ 's are statically significant. To verify the existence of a long-run relationship between GP and $\mathrm{CPI}$ and between GP and TL/US dollar, the Granger causality test within a VECM is implemented. Formally, different possible Granger causal relations between GP and CPI and between GP and TL/US dollar in levels can be expressed using the parameters of equations (1), (2), (3), and (4) which form VECMs:

$$
\begin{aligned}
& G P_{t}=a_{0}+\sum_{i=1}^{m} a_{i} \cdot G P_{t-i}+\sum_{j=1}^{m} b_{j} \cdot C P I_{t-j}+u_{t} \\
& C P I_{t}=b_{0}+\sum_{j=1}^{m} b j \cdot C P I_{t-j}+\sum_{i=1}^{m} a_{i} \cdot G P_{t-i}+v_{t} \\
& G P_{t}=c_{0}+\sum_{i=1}^{m} c_{i} \cdot G P_{t-i}+\sum_{j=1}^{m} d_{j} \cdot(T L / U S \$)_{t-j}
\end{aligned}
$$

$$
(T L / U S \$)_{t}=d_{0}+\sum_{j=1}^{m} d j \cdot(T L / U S \$)_{t-j}+\sum_{i=1}^{m} c_{i} \cdot G P_{t-i}+w_{t}
$$

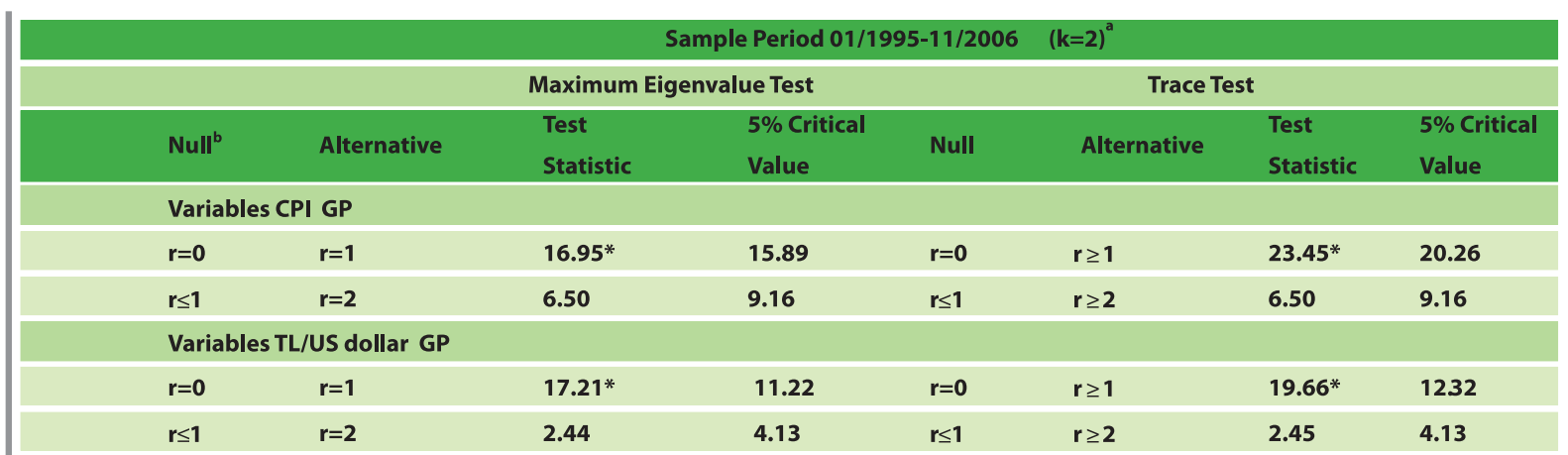

\section{Table 2. Johansen Cointegration Tests}

a The optimal lag length $\mathrm{k}$ was selected based on SIC in vector autoregressive (VAR) representation. $\mathrm{b} r$ is the number of cointegrating vectors.

* Denotes significance at the $5 \%$ level. 
where $u_{t^{\prime}} v_{t^{\prime}} e_{t}$ and $w_{t}$ are the white-noise error terms.

The results of Granger causality test are presented in Table 3. The null hypothesis that GP does not Granger cause CPI is rejected, while it is not possible to reject the null hypothesis that CPI does not Granger cause GP. The null hypothesis of GP does not Granger cause TL/US dollar exchange rate is rejected, but the rejection of the hypothesis that TL/US dollar exchange rate does not Granger cause GP could not be possible. In other words, GP Granger causes the CPI and TL/US dollar exchange rate in a unidirectional way.

\begin{tabular}{|l|l|}
\hline Null Hypothesis & Chi -sq \\
\hline GP does not Granger Cause CPI & $10.23^{*}$ \\
\hline CPI does not Granger Cause GP & 2.08 \\
\hline GP does not Granger Cause TL/US dollar & $20.21^{*}$ \\
\hline TL/US dollar does not Granger Cause GP & 3.26 \\
\hline
\end{tabular}

Table 3. Granger Causality Tests Based on VECM

* Denotes significance at the $5 \%$ level. $5 \%$ critical value for the Chi-sq test is 5.99 .

\section{Concluding Remarks}

In this paper, it is analyzed whether gold is an internal hedge and/or an external hedge against a TL. First, the stationarity properties of the GP, CPI, and TL/US dollar exchange rate series were determined. Then the cointegration framework of Johansen (1988) was applied to test for cointegrating relationships. All tests confirmed the existence of long-term relationships between GP and CPI and between GP and TL/US dollar exchange rate. Furthermore, in order to determine the causal relationships between CPI and GP and between TL/US dollar exchange rate and GP, Granger Causality Test is used based on VECM The results indicated that GP Granger caused the CPI and TL/US dollar exchange rate (i.e., changes in GP preceded changes in the CPI and TL/US dollar exchange rate) in a unidirectional way. Therefore, it is concluded that gold acts as an effective hedge against future possible TL depreciation and rising inflation. The results also suggest that gold price is an indicator of expected inflation and hence it can be used as a guide for the direction of monetary policy. 모

\section{References}

Capie, F., T.C., Mills, and G., Wood, 2005, "Gold as a Hedge Against the Dollar", Journal of International Financial Markets, Institutions and Money 15.

Central Bank of the Republic of Turkey, http://www.tcmb. gov.tr

Chua, J., G., Stick, and R., Woodward, 1990, "Diversifying with Gold Stocks" Financial Analysts Journal 46.

Ciner, C., 2001, "On the Long-run Relationship Between Gold and Silver:A note", Global Finance Journal 12.

Dickey, D.A., and W.A., Fuller, 1979, "Distribution of the Estimators for Autoregressive Series with a Unit Root", Journal of American Statistical Association 74.

Engle, R.F., and C.W., Granger, 1987, "Co-integration and Error Correction: Representation, Estimation, and Testing", Econometrica 55.

Garner, C., 1995, "How Useful are Leading Indicators of Inflation", Economic Review, Federal Reserve Bank of Kansas City 80:2.

Ghosh, D.L., E.J., Macmillan, and R.E., Wright, 2002, "Gold as an Inflation Hedge?", University of St. Andrews Discussion Paper Series, Department of Economics, No.21.

Granger, C.W., 1969, "Investigating Causal Relations by Econometric Models and Cross-spectial Methods", Econometrica 37:3.

Harmston, S., 1998, "Gold as a Store of Value", World Gold Council, Research Study No.22, http://www.gold.org/ value/reserve_asset/index.html. Accessed May 2007.

Jaffe, J., 1989, "Gold and Gold Stocks as Investments for Institutional Portfolios", Financial Analysts Journal 45.

Johansen, S., 1988, "Statistical Analysis of Cointegration Vectors", Journal of Economic Dynamics and Control 12:2.

Kitchen, J., 1996, “Domestic and International Financial Market Responses to Federal Deficit Announcements", Journal of International Money and Finance 15.

Laurent, R.D., 1994, "Is There a Role for Gold in Monetary Policy?", Economic Perspectives, The Federal Reserve Bank of Chicago 18:2.

Levin, E.R., and R.E., Wright, 2006, "Short-run and Longrun Determinants of the Price ofGold",WorldGoldCouncil, ResearchStudyNo.32,http://www.gold.org/value/reserve_ asset/index.html, Accessed May 2007. 
Lucey, B., and E., Tully, 2006, "Seasonality, Risk and Return in Daily Comex Gold and Silver 1980 - 2002", Applied Financial Economics 16.

Mahdavi, S., and S., Zhou, 1997, "Gold and Commodity Prices as Leading Indicators of Inflation: Tests of LongRun Relationship and Predictive Performance", Journal of Economics and Business 49

Michaud, R., R., Michaud, and K., Pulvermacher, 2006, "Gold as a Strategic Asset", World Gold Council, http:// www.gold.org/value/stats/research/index.html, Accessed May 2007.

Phillips, P.C.B., and P., Peron, 1988, “Testing for a Unit Root in Time Series Regression", Biometrika 75.

Ranson, D., and H.C., Wainright, 2005, "Why Gold, not Oil, is the Superior Predictor of Inflation", Gold Report, World Gold Council, November.

Sherman, E., 1986, Gold Investment:Theory and Application, New York, Prentice Hall.

Tandon, K., and T., Urich, 1987, "Internationa Market Response to Announcements of US Macroeconomic Data", Journal of International Money and Finance 6.

The World Gold Council,2005, "The Value of Gold to Society", http://www.gold.org/pub_archive/index.php?thi sDomain $\mid \mathrm{D}=$ value\&thisSubDomain $\mid \mathrm{D}=$ stats

Turkish Statistical Institute, http://www.turkstat.gov.tr 